\title{
VITAMIN D-RESISTANT RICKETS: THE EFFECT OF CALCIUM INFUSION ON PHOSPHATE REABSORPTION *
}

\author{
By MORTON H. FIELD † AND ERIC REISS $\ddagger$ \\ (From the Departments of Medicine (Metabolism Division) and Preventive Medicine (Irene \\ Walter Johnson Institute of Rehabilitation), Washington University School of \\ Medicine, St. Louis, Mo.)
}

(Submitted for publication October 14, 1959; accepted August 3, 1960)

Vitamin D-resistant rickets (R.R.) is a genetically transmitted form of rickets that fails to respond to treatment with nutritional doses of vitamin D. It is characterized by a low serum phosphorus, a normal serum calcium, and an elevated serum alkaline phosphatase, and is transmitted by a sex-linked dominant inheritance pattern (2).

In the first detailed study of R.R., Albright, Butler and Bloomberg (3) demonstrated poor intestinal absorption of calcium and hyperphosphaturia. Nutritional doses of vitamin D had no effect on these metabolic abnormalities, but massive doses improved calcium absorption and decreased the hyperphosphaturia. ${ }^{1}$ Albright and colleagues therefore suggested that the poor absorption of calcium was a stimulus for increased parathyroid hormone secretion, which in turn caused the hyperphosphaturia.

In recent years, many studies of R.R. have demonstrated that the fraction of filtered phosphate reabsorbed (TRP) is low despite the presence of a low serum phosphorus concentration. Considering this finding and the similarity of R.R. to the Fanconi syndrome and renal glycosuria, Dent and Harris $(4,5)$, Fanconi $(6)$ and others have concluded that R.R. is caused by an isolated renal tubular defect of phosphate reabsorption. This opinion has been widely accepted and has led to general usage of the term "phosphate diabetes" as a synonym for the disease.

* Presented in part at the 51st Annual Meeting of the American Society for Clinical Investigation, Atlantic City, N. J., May 1959 (1).

+ Trainee in metabolism.

$¥$ American Cancer Society Scholar in Medicine.

1 The urinary phosphate excretion may not be increased in absolute quantities. However, it is always greater than normal considering the low serum phosphorus concentration. In the absence of hyperparathyroidism or a renal tubular defect, a low serum phosphorus concentration is associated with a very low urinary phosphate excretion.
The present studies were performed to distinguish between a primary tubular defect and extra-renal causes for the hyperphosphaturia in R.R. If the hypothesis of Albright is correct, an elevation of the serum calcium by the infusion of calcium salts should abolish the secondary hyperparathyroidism and, consequently, increase the phosphate reabsorption. On the other hand, if an absolute intrinsic defect of renal phosphate transport exists, the calcium infusion should have little effect on phosphate reabsorption.

The infusion of calcium in R.R. was associated with a definite increase of phosphate reabsorption. This evidence, combined with appropriate control studies, indicated that extra-renal factors are in part responsible for the characteristic pattern of phosphate reabsorption.

\section{MATERIAL AND METHODS}

Eight patients, 7 females and 1 male, with the characteristic features of R.R. were studied. They were derived from 3 families belonging to a group of patients under observation at the Shriners Hospital of St. Louis (7). The patients selected for study had received no vitamin D therapy for at least 3 years and had not had any orthopedic operations resulting in immobilization for at least 1 year before the study. The age of the patients ranged between 7 and 53 years. Physical and laboratory examinations were done to exclude acidosis, glycosuria, aminoaciduria, overt renal impairment, infection, or other intercurrent illnesses.

Ten control subjects were studied. These included 2 normal medical students, 4 normal siblings of patients with R.R., and 4 patients on the general medical wards of Barnes Hospital who were under observation for diseases unrelated to skeletal or metabolic disease and did not receive treatment during the study. The results obtained in the 4 siblings were indistinguishable from those in other normal control subjects and were therefore included in the control group. A patient with postoperative hypoparathyroidism was also studied.

Phosphate and creatinine clearances were measured simultaneously in the postabsorptive state. Patients were given $1 \mathrm{~L}$ of water orally at the beginning of each study 
and additional water throughout the study in order to assure adequate urine flows. Clearance periods varied from 2 to 4 hours, and 5 to 6 clearance periods were obtained in each study. Urine was collected by voiding. Samples of venous blood were obtained at the mid-point of each period. Phosphorus was determined by the method of Gomori (8) and creatinine by the method of Folin as modified by Hawk, Oser and Summerson (9). In 50 normal adult subjects, the creatinine clearance measured with this method averaged $95 \mathrm{ml}$ per minute (range, 70 to 110). Calcium was determined by flame photometry (Coleman flame photometer, model 21). The results are expressed as amount of phosphate reabsorbed per minute and as per cent TRP. It is assumed that all of the inorganic serum phosphate is ultrafiltrable and that the excreted phosphate represents the portion of filtered phosphate which is not reabsorbed. Phosphate secretion by the tubules has been demonstrated in the chicken (10) and has been suggested by recent studies in the $\operatorname{dog}(11,12)$. To our knowledge, however, there is no convincing evidence of tubular phosphate secretion in man. Since the clearances of phosphate and creatinine were determined from measurements performed on the same samples of blood and urine, it should be noted here that errors due to incomplete bladder emptying did not affect the calculated value of the TRP.

For at least 3 days before an infusion, the subjects were given a hospital diet supplemented by a minimum of 1 quart of milk daily in order to assure an adequate phosphate intake. After an overnight fast with an unrestricted intake of water, 1 or 2 control clearance periods were obtained. An infusion of $15 \mathrm{mg}$ of calcium per $\mathrm{kg}$ of body weight as the gluconate-glucoheptonate (Abbot) in saline was then given intravenously at a

TABLE I

Patterns of renal excretion of phosphate before, during and after infusion of calcium*

\begin{tabular}{|c|c|c|c|c|c|c|c|c|}
\hline Age & Period & $\begin{array}{l}\text { Creatinine } \\
\text { clearance }\end{array}$ & $\underset{P}{\text { Serum }}$ & $\underset{\mathrm{P}}{\text { Filtered }}$ & $\underset{P}{\text { Excreted }}$ & $\underset{P}{\text { Reabsorbed }}$ & TRP & $\underset{\mathrm{Ca}}{\text { Serum }}$ \\
\hline yrs & & $m l / m i n \dagger$ & \multicolumn{2}{|c|}{$A$. Normal subjects } & 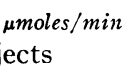 & & $\%$ & $m g / 100 \mathrm{ml}$ \\
\hline 33 & $\begin{array}{l}A \\
B \\
C \\
D \\
E\end{array}$ & $\begin{array}{l}67.1 \\
66.7 \\
68.3 \\
67.6 \\
68.1\end{array}$ & $\begin{array}{l}4.90 \\
4.82 \\
5.37 \\
5.84 \\
6.23\end{array}$ & $\begin{array}{l}106 \\
104 \\
118 \\
127 \\
137\end{array}$ & $\begin{array}{l}20.4 \\
14.2 \\
15.6 \\
15.6 \\
19.6\end{array}$ & $\begin{array}{l}85.6 \\
89.8 \\
102 \\
111 \\
117\end{array}$ & $\begin{array}{l}80.9 \\
86.3 \\
86.4 \\
87.4 \\
85.4\end{array}$ & $\begin{array}{l}10.1 \\
11.4 \\
12.3 \\
12.7 \\
11.7\end{array}$ \\
\hline 52 & $\begin{array}{l}\text { A } \\
\text { B } \\
\text { C } \\
\text { D } \\
\text { E }\end{array}$ & $\begin{array}{c}90.4 \\
123 \\
106 \\
80.4 \\
70.2\end{array}$ & $\begin{array}{l}3.59 \\
3.91 \\
4.39 \\
4.77 \\
5.16\end{array}$ & $\begin{array}{l}104 \\
155 \\
150 \\
124 \\
117\end{array}$ & $\begin{array}{r}9.5 \\
14.4 \\
16.1 \\
13.2 \\
8.5\end{array}$ & $\begin{array}{l}94.5 \\
141 \\
134 \\
111 \\
108\end{array}$ & $\begin{array}{l}90.9 \\
91.0 \\
89.3 \\
89.4 \\
92.3\end{array}$ & $\begin{array}{r}9.5 \\
10.4 \\
12.2 \\
12.0 \\
11.4\end{array}$ \\
\hline \multicolumn{9}{|c|}{$B$. Rachitic subjects } \\
\hline 7 & $\begin{array}{l}\text { A } \\
\text { B } \\
\text { C } \\
\text { D } \\
\text { E }\end{array}$ & $\begin{array}{l}66.8 \\
77.1 \\
88.8 \\
81.5 \\
77.5\end{array}$ & $\begin{array}{l}1.86 \\
1.94 \\
2.17 \\
2.55 \\
2.55\end{array}$ & $\begin{array}{l}40.1 \\
48.3 \\
62.2 \\
67.0 \\
63.8\end{array}$ & $\begin{array}{l}26.5 \\
16.2 \\
26.9 \\
10.7 \\
17.4\end{array}$ & $\begin{array}{l}13.6 \\
32.1 \\
35.3 \\
56.3 \\
46.4\end{array}$ & $\begin{array}{l}33.9 \\
66.4 \\
56.7 \\
84.0 \\
72.7\end{array}$ & $\begin{array}{l}10.2 \\
11.2 \\
12.7 \\
10.7 \\
10.8\end{array}$ \\
\hline 16 & $\begin{array}{l}\mathrm{A} \\
\mathrm{B} \\
\mathrm{C} \\
\mathrm{D} \\
\mathrm{E}\end{array}$ & $\begin{array}{l}106 \\
108 \\
133 \\
106 \\
137\end{array}$ & $\begin{array}{l}2.54 \\
2.67 \\
2.98 \\
3.03 \\
3.01\end{array}$ & $\begin{array}{c}86.8 \\
93.0 \\
128 \\
104 \\
133\end{array}$ & $\begin{array}{l}16.9 \\
19.0 \\
15.1 \\
10.3 \\
11.0\end{array}$ & $\begin{array}{c}69.9 \\
74.0 \\
113 \\
93.7 \\
122\end{array}$ & $\begin{array}{l}80.5 \\
79.6 \\
88.3 \\
90.1 \\
91.7\end{array}$ & $\begin{array}{r}9.9 \\
11.1 \\
12.0 \\
11.7 \\
9.9\end{array}$ \\
\hline 18 & $\begin{array}{l}\text { A } \\
\text { B } \\
\text { C } \\
\text { D } \\
\text { E }\end{array}$ & $\begin{array}{c}120 \\
120 \\
115 \\
105 \\
96.5\end{array}$ & $\begin{array}{l}2.11 \\
2.50 \\
2.73 \\
2.78 \\
2.51\end{array}$ & $\begin{array}{c}81.7 \\
96.8 \\
101 \\
94.2 \\
78.1\end{array}$ & $\begin{array}{r}19.3 \\
17.8 \\
13.2 \\
5.8 \\
6.1\end{array}$ & $\begin{array}{l}62.4 \\
79.0 \\
87.8 \\
88.4 \\
72.0\end{array}$ & $\begin{array}{l}76.4 \\
81.6 \\
86.9 \\
93.8 \\
92.2\end{array}$ & $\begin{array}{r}9.6 \\
11.8 \\
12.4 \\
11.6 \\
10.1\end{array}$ \\
\hline 53 & $\begin{array}{l}A \\
B \\
C \\
D \\
E\end{array}$ & $\begin{array}{c}106 \\
97.6 \\
108 \\
147 \\
118\end{array}$ & $\begin{array}{l}1.92 \\
2.06 \\
2.98 \\
3.55 \\
3.51\end{array}$ & $\begin{array}{c}65: 7 \\
64.8 \\
104 \\
168 \\
134\end{array}$ & $\begin{array}{r}10.0 \\
5.7 \\
7.6 \\
10.8 \\
4.9\end{array}$ & $\begin{array}{r}55.7 \\
59.1 \\
96.4 \\
157.2 \\
129\end{array}$ & $\begin{array}{l}84.8 \\
91.2 \\
92.7 \\
93.6 \\
96.3\end{array}$ & $\begin{array}{r}9.7 \\
10.6 \\
11.6 \\
11.9 \\
11.2\end{array}$ \\
\hline
\end{tabular}

* Period A, before infusion (average of two 2-hour or one 4-hour clearance); Periods B and C, during infusion (two consecutive 2-hour clearances); Periods D and E, after infusion (two consecutive 2-hour clearances). $\mathrm{P}=$ phosphorus; TRP $=$ tubular reabsorption of phosphate $; \mathrm{Ca}=$ calcium.

† Corrected to $1.73 \mathrm{~m}^{2}$ body surface. 
constant rate over 4 hours. Two clearance periods of 2 hours each were obtained during the infusion and 2 immediately following the infusion.

\section{RESULTS}

Normal subjects. The mean response of the TRP during the calcium infusion studies in 10 subjects is shown in Figure 1, and details of two representative studies are shown in Table I, $A$. On a random diet, the baseline TRP in normal subjects in this laboratory is $85 \pm 3$ per cent, with 95 per cent confidence limits of 77 to 93 per cent (13). The serum phosphorus increased during the infusion in every case, in agreement with previously reported data (14). The creatinine clearance remained constant or increased. As a result of these changes, the filtered load of phosphate always increased. In general, the reabsorbed phosphate increased in proportion to the filtered phosphate so that the TRP rose only slightly (Figure 1). During and following the infusion, the phosphate reabsorption was often very high and in the range of values of maximal tubular phosphate reabsorption reported by Thompson and Hiatt [ (15), Table I, $A$ ].

Rachitic subjects. The mean response of the TRP during the calcium infusion studies in the eight rachitic subjects is shown in Figure 2, and

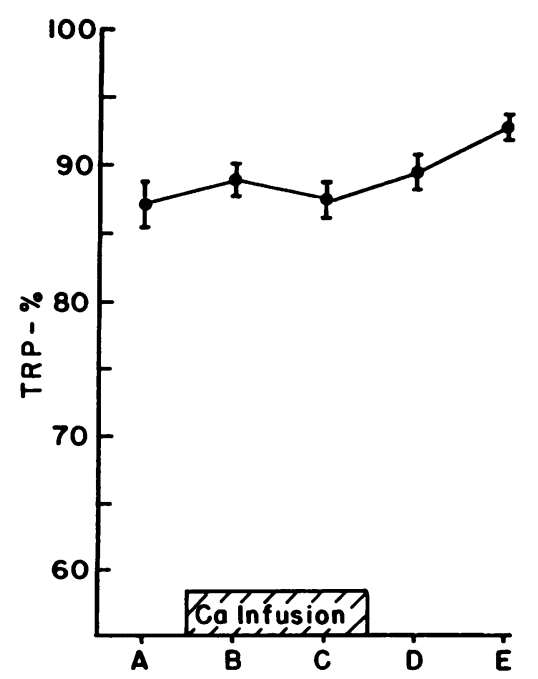

Fig. 1. EFFECT OF CALCIUM INFUSION ON FILTERED PHOSPHATE REABSORBED (TRP) IN TEN NORMAL SUBJECTS. Mean \pm 1 SE. A was a 4 hour control period; all other clearance periods extended over 2 hours; $15 \mathrm{mg}$ of calcium per $\mathrm{kg}$ of body weight was infused at a constant rate over 4 hours.

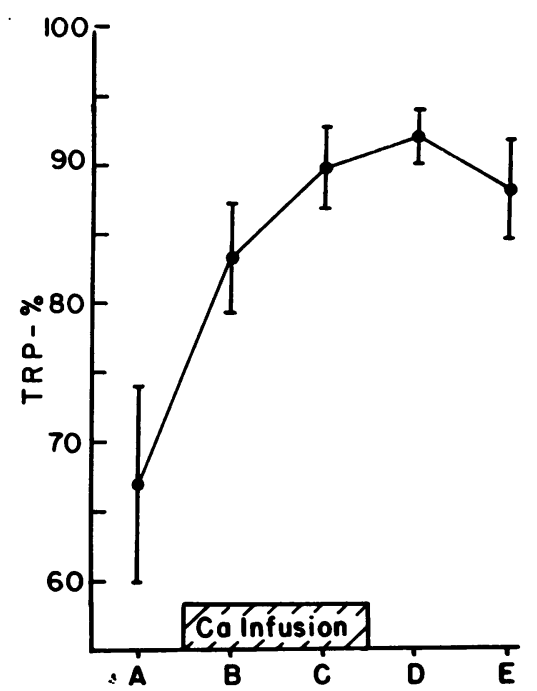

Fig. 2. EFfect of CAlcium infusion on TRP IN EIGHT RACHITIC subjects. Mean $\pm 1 \mathrm{SE}$. A was a 4-hour control period; all other clearance periods extended over 2 hours; $15 \mathrm{mg}$ of calcium per $\mathrm{kg}$ of body weight was infused at a constant rate over 4 hours.

details of four representative studies are shown in Table I, $B$. The serum phosphorus always increased during the infusion, as it did in normal subjects, and changes in the creatinine clearance were variable with a tendency toward an increase during the infusion. Both filtered and reabsorbed phosphate always increased. However, the reabsorbed phosphate increased more than the filtered so that the fraction of TRP increased markedly.

Hypoparathyroid patient. In order to test the possibility that a calcium infusion may alter renal phosphate transport independently of changes in parathyroid activity, the effects of a calcium infusion were studied in a hypoparathyroid subject who was maintained on constant doses of parathyroid extract (Table II). The patient developed hypoparathyroidism after a thyroidectomy three years previously and had not received vitamin D for four months before the study. Parathyroid extract (Lilly) was administered for the three day period preceding the study. On the day of the calcium infusion study, parathyroid extract was given intravenously at a constant rate.

Administration of parathyroid extract resulted in a striking increase of the creatinine clearance. However, owing to the concurrent decrease of the serum phosphorus concentration from 5.8 to 2.6 $\mathrm{mg}$ per $100 \mathrm{ml}$, the filtered phosphate decreased 
TABLE II

Pattern of renal excretion of phosphate in a hypoparathyroid subject $*$

\begin{tabular}{|c|c|c|c|c|c|}
\hline $\begin{array}{l}\text { Creati- } \\
\text { nine } \\
\text { clearance }\end{array}$ & $\underset{\mathbf{P}}{\operatorname{Serum}}$ & $\underset{\mathrm{P}}{\text { Filtered }}$ & $\underset{P}{\text { Excreted }}$ & $\begin{array}{c}\text { Reab- } \\
\text { sorbed } \\
\text { P }\end{array}$ & TRP \\
\hline \multicolumn{2}{|c|}{$\begin{array}{l}\mathrm{ml} / \mathrm{min} \dagger \mathrm{mg} / 100 \mathrm{ml} \\
\text { Baseline }\end{array}$} & \multicolumn{3}{|c|}{$\mu m o l e s / \min$} & $\%$ \\
\hline 57.0 & 5.81 & 107 & 5.5 & 103 & 96.2 \\
\hline \multicolumn{6}{|c|}{ After 3 days' i.m. parathyroid extract, $200 \mathrm{U}$ q6hr } \\
\hline 118 & 2.59 & 98.6 & 20.9 & 77.7 & 78.8 \\
\hline \multicolumn{6}{|c|}{$\begin{array}{l}2 \text { hrs after i.v. parathyroid extract, } 50 \mathrm{U} / \mathrm{hr} \text {, maintained through- } \\
\text { out remainder of experiment }\end{array}$} \\
\hline 106 & 2.58 & 88.2 & 24.4 & 63.8 & 72.3 \\
\hline \multicolumn{6}{|c|}{ During calcium infusion, $15 \mathrm{mg} / \mathrm{kg}$} \\
\hline $\begin{array}{l}115 \\
117\end{array}$ & $\begin{array}{l}2.86 \\
2.99\end{array}$ & $\begin{array}{l}106 \\
113\end{array}$ & $\begin{array}{l}28.4 \\
37.0\end{array}$ & $\begin{array}{l}77.6 \\
76.0\end{array}$ & $\begin{array}{l}73.2 \\
67.2\end{array}$ \\
\hline \multicolumn{6}{|c|}{ Following calcium infusion } \\
\hline $\begin{array}{l}112 \\
109\end{array}$ & $\begin{array}{l}3.27 \\
3.52\end{array}$ & $\begin{array}{l}118 \\
124\end{array}$ & $\begin{array}{l}41.4 \\
40.7\end{array}$ & $\begin{array}{r}76.9 \\
-83.3\end{array}$ & $\begin{array}{l}65.2 \\
67.2\end{array}$ \\
\hline
\end{tabular}

$* \mathrm{P}=$ phosphorus; $\mathrm{TRP}=$ tubular reabsorption of phosphate The first two clearance periods lasted 4 hours, the others 2 hours.

$\dagger$ Corrected to $1.73 \mathrm{~m}^{2}$ body surface.

slightly (from 107 to $99 \mu$ moles per minute). The reabsorbed phosphate fell from 103 to 78 $\mu$ moles per minute while a 4.6 -fold increase of phosphate excretion occurred. A transitory decrease of filtered as well as reabsorbed phosphate occurred 2 hours after beginning the intravenous infusion of parathyroid extract. During and following the infusion of calcium, the filtered phosphate increased, chiefly as a result of an increase of the serum phosphorus concentration, while the reabsorbed remained nearly constant at approximately $77 \mu$ moles per minute. The TRP consequently decreased. This response should be contrasted with that of patients whose parathyroid glands are intact: in the presence of the glands, the invariable increase of the filtered phosphate induced by the calcium infusion was associated with a disproportionately large increase of the reabsorbed phosphate and therefore an increase of the TRP.

\section{DISCUSSION}

The literature contains brief references to the use of intravenous infusions of calcium in the differentiation between intrinsic renal and extrarenal causes of impaired phosphate reabsorption in R.R. Lamy, Royer, Frézal and Lestradet (16) noted a decrease in phosphaturia and an increase of the TRP from 82 to 98 per cent during a calcium infusion in a patient with typical R.R. Lestradet, Royer and Jacob (17) studied five patients with R.R. before and following an infusion of calcium. A moderate increase of the TRP was noted in three patients and a decrease in the two other patients. However, this study was not comparable with the present one because the calcium was administered in a solution containing 4 per cent glucose; the infusion of glucose was likely to be associated with a decrease of the serum phosphorus concentration. Data on changes in serum phosphorus concentration and details of phosphate excretion were not given. In their review of the literature on R.R., Winters, Graham, Williams, $\mathrm{McFalls}$ and Burnett (2) refer to unpublished observations on the effects of a calcium infusion in two patients with R.R. The phosphaturia was diminished, but "phosphorus did not completely disappear from the urine as would have been expected in the presence of marked hypophosphatemia, if the resorptive mechanism had been converted to complete normality. . . ." Fraser, Leeming, Cerwenka and Kenyeres (18) published preliminary observations on two patients with R. R. with calcium infusions and noted rapid diminution of the excessive urinary output of phosphorus throughout the period of calcium infusion.

In the present studies, the infusion of calcium was associated with a striking increase of the rate of phosphate reabsorption in every case. This observation indicates that extra-renal factors are of major importance in causing the abnormal pattern of phosphate excretion in R.R. It is not possible to state whether phosphate reabsorption was completely restored to "normal" by the calcium infusion, because phosphate reabsorption is highly variable in normal subjects. This is true both under baseline conditions and during phosphate loading. The maximal tubular reabsorptive rate often does not attain a consistent value in subjects studied repeatedly (15). Although parathyroid extract is known to decrease the $\mathrm{Tm}_{\mathrm{p}}$, there is a considerable overlap of values of the $\mathrm{Tm}_{\mathrm{p}}$ in normal and hypoparathyroid subjects $(15,19)$. During and following the calcium infusion, phosphate reabsorption in the rachitic subjects often attained values within the range of the normal $\mathrm{Tm}_{\mathrm{p}}$, even though the plasma concentration of phosphorus was far below that which is commonly reached in studies of the $\mathrm{Tm}_{\mathrm{p}}$, and full saturation of the transport system for phosphate would therefore not be expected. 
In recent years, the TRP has been widely used as an indirect measure of parathyroid function. The TRP is low in hyperparathyroidism and high in hypoparathyroidism (20). It is not, however, a specific measure of parathyroid function. The TRP is not a discrete measure of phosphate transport but a ratio relating tubular reabsorption of phosphate to the filtered load of phosphate. This seems to be an appropriate expression for the following reasons. 1) Comparison between normal and rachitic subjects is facilitated by factoring reabsorbed phosphate by the filtered load; the filtered load decidedly affects reabsorption and is always low in the rachitic subjects owing to the characteristic hypophosphatemia. 2) It was of interest to explore the possibility that changes in phosphate reabsorption during the calcium infusion might be related to changes in parathyroid function. Crawford, Osborne, Talbot, Terry and Morrill (21) have shown that the TRP is a more sensitive index of parathyroid function than the absolute rate of phosphate reabsorption: the TRP has an essentially constant high value in parathyroidectomized animals and promptly decreases when parathyroid extract is administered. The impressive increase of the TRP during and following the calcium infusions may therefore be related to decreasing parathyroid function. While this conclusion is open to doubt in the absence of more direct measures of parathyroid function, it is consistent with the available data. The control observation in the subjects with hypoparathyroidism receiving a constant amount of parathyroid extract lends support to this explanation by showing that the calcium infusion does not induce an increase of the TRP when fluctuations of parathyroid function are not possible. The small decrease of the TRP actually observed in this experiment is consistent with the increase of filtered phosphate, which may by itself cause a slight depression of the TRP in the hypoparathyroid state (22).

The present experiments do not shed any light on the important observation that there are carriers of R.R. who have hypophosphatemia without overt bone disease $(2,23)$. Active bone disease is believed to develop because the concentration of serum phosphorus is so low as to prevent normal calcification of osteoid. It is known that sera obtained from rachitic patients fail to effect normal calcification of rachitic rat cartilage in vitro (24, 25) and that rapid calcification can be achieved in rachitic subjects by the continued infusion of phosphate and calcium (25). These observations focus attention on the hypophosphatemia as the immediate precursor of the bone disease and appear to show that an intrinsic defect of bone does not exist. The existence of asymptomatic carriers of the disease represents a paradox that holds the key to a more comprehensive explanation of the etiology of R.R.

\section{SUMMARY}

1. The effects of the intravenous infusion of calcium were studied in patients with vitamin D-resistant rickets and in control subjects. The infusion of calcium consistently increased the low tubular reabsorption of phosphate of resistant rickets to nearly normal levels.

2. The calcium infusions were always accompanied by an increase in the serum phosphorus, the filtered phosphate, and the reabsorbed phosphate. This is interpreted as suggesting decreased parathyroid function.

3. It is concluded that secondary hyperparathyroidism, presumably due to defective gastrointestinal absorption of calcium, accounts, at least in part, for the phosphaturia and the hypophosphatemia characteristic of the disease.

\section{ACKNOWLEDGMENTS}

The authors are deeply indebted to Dr. William $\mathrm{H}$. Daughaday for his advice and encouragement; to Drs. George Scheer and Warren Stamp and the staff at Shriners Hospital of St. Louis for their generous help; and to Miss Lois Leong and Miss Claudia Riley for technical assistance. Parathyroid extract was generously supplied by the Eli Lilly Company.

\section{REFERENCES}

1. Field, M. H., and Reiss, E. "Vitamin D-resistant rickets": A disease associated with normal renal transport of phosphate (abstract). J. clin. Invest. $1959,38,1004$.

2. Winters, R. W., Graham, J. B., Williams, T. F., McFalls, V. W., and Burnett, C. H. A genetic study of familial hypophosphatemia and vitamin $D$ resistant rickets with a review of the literature. Medicine (Baltimore) 1958, 37, 97.

3. Albright, F., Butler, A. M., and Bloomberg, E. Rickets resistant to vitamin D therapy. Amer. J. Dis. Child. 1937, 54, 529. 
4. Dent, C. E. Rickets and osteomalacia from renal tubule defects. J. Bone Jt Surg. 1952, 34-B, 266.

5. Dent, C. E., and Harris, H. Hereditary forms of rickets and osteomalacia. J. Bone Jt Surg. 1956, 38-B, 204.

6. Fanconi, G. Variations in sensitivity to vitamin D; from vitamin $\mathrm{D}$ resistant rickets, vitamin $\mathrm{D}$ avitaminotic rickets and hypervitaminosis $\mathrm{D}$ to idiopathic hypercalcaemia in Bone Structure and $\mathrm{Me}-$ tabolism, G. E. W. Wolstenholme and C. M. O'Connor, Eds. Ciba Found. Symp. Boston, Little, Brown, 1956; p. 187.

7. Pedersen, H. E., and McCarroll, H. R. Vitaminresistant rickets. J. Bone Jt Surg. 1951, 33-A, 203.

8. Gomori, G. A modification of the colorimetric phosphorus determination for use with the photoelectric colorimeter. J. Lab. clin. Med. 1942, 27, 955.

9. Hawk, P. B., Oser, B. L., and Summerson, W. H. Practical Physiological Chemistry, 13th ed. New York, Blakiston, 1954, pp. 557, 900.

10. Levinsky, N. G., and Davidson, D. G. Renal action of parathyroid extract in the chicken. Amer. J. Physiol. 1957, 191, 530.

11. Nicholson, T. F., and Shepherd, G. W. The effect of damage to various parts of the renal tubule on the excretion of phosphate by the dog's kidney. Canad. J. Biochem. 1959, 37, 103.

12. Carrasquer, G., and Brodsky, W. A. Secretion of phosphate in the mammalian kidney after closearterial injection. Fed. Proc. 1959, 18, 24.

13. Reiss, E., and Alexander, F. The tubular reabsorption of phosphate in the differential diagnosis of metabolic bone disease. J. clin. Endocr. 1959, 19, 1212.

14. Howard, J. E., Hopkins, T. R., and Connor, T. B. On certain physiologic responses to intravenous injection of calcium salts into normal, hyperparathyroid and hypoparathyroid persons. J. clin. Endocr. 1953, 13, 1.

15. Thompson, D. D., and Hiatt, H. H. Renal reabsorption of phosphate in normal human subjects and in patients with parathyroid disease. J. clin. Invest. $1957,36,550$.
16. Lamy, M., Royer, P., Frézal, J., and Lestradet, H. Le rachitisme vitamino-résistant familial hypophosphatémique primitif. Arch. franç. Pédiat. 1958, 15, 1.

17. Lestradet, H., Royer, P., and Jacob, D. Résultats fournis par l'épreuve de perfusion calcique dans le rachitisme vitamino-résistant hypophosphatémique idiopathique. Rev. franç. Et. clin. biol. 1958, 3, 884.

18. Fraser, D., Leeming, J. M., Cerwenka, E. A., and Kenyeres, K. Studies of the pathogenesis of the high renal clearance of phosphate in hypophosphatemic vitamin D-refractory rickets of the simple type (abstract). A.M.A. Amer. J. Dis. Child. 1959, 98, 586.

19. Hiatt, H. H., and Thompson, D. D. The effects of parathyroid extract on renal function in man. J. clin. Invest. 1957, 36, 557.

20. Chambers, E. L., Jr., Gordon, G. S., Goldman, L., and Reifenstein, E. C., Jr. Tests for hyperparathyroidism: Tubular reabsorption of phosphate, phosphate deprivation, and calcium infusion. J. clin. Endocr. 1956, 16, 1507.

21. Crawford, J. D., Osborne, M. M., Jr., Talbot, N. B., Terry, M. L., and Morrill, M. F. The parathyroid glands and phosphorus homeostasis. J. clin. Invest. 1950, 29, 1448.

22. Foulks, J. G., and Perry, F. A. Renal excretion of phosphate following parathyroidectomy in the dog. Amer. J. Physiol. 1959, 196, 554.

23. Graham, J. B., McFalls, V. W., and Winters, R. W. Familial hypophosphatemia with vitamin D-resistant rickets. II : Three additional kindreds of the sex-linked dominant type with a genetic analysis of four such families. Amer. J. hum. Genet. 1959, 11, 311.

24. Shipley, P. G., Kramer, B., and Howland, J. Calcification of rachitic bones in vitro. Amer. J. Dis. Child. 1925, 30, 37.

25. Fraser, D., Taco, N. T., Yendt, E. R., Munn, J. D., and Liu, E. Induction of in vitro and in vivo calcification in bones of children suffering from vitamin D-resistant rickets without recourse to large doses of vitamin D (abstract). A.M.A. Amer. J. Dis. Child. 1957, 93, 84. 